Федянович Д. Л., канд. військ. наук, ст. наук. співроб.

$(0000-0002-9896-8655)$

Возняк С. М., канд. техн. наук, ст. наук. співроб.

$(0000-0002-9015-813 \mathrm{X})$

Доброгурський В. I.

(0000-0002-5263-6102)

Національний університет оборони України імені Івана Черняховського, Київ

\title{
Рекомендації щодо протидії агентам впливу та рухам опору, які діють в інтересах держави-ініціатора гібридної агресії
}

Резюме. Запропоновано рекомендації щодо протидії агентам впливу та рухам опору, які діють в інтересах держави-агресора. Визначено основні сфери національної безпеки та об'єкти впливу, на які спрямована дія агентів впливу. Розкрито роль агентів впливу у дестабілізації суспільно-політичної обстановки. Запропоновано методи боротьби з агентами впливу, які доцільно застосовувати на прихованій фазі гібридної агресії. Наведено напрями удосконалення асиметричної протидії гібридним загрозам завдяки вирішенню проблемних питань протидії агентам впливу та рухам опору.

Ключові слова: агенти впливу; асиметрична протидія; гібридна агресія; рух опору; спеціальна операція; методи протидії; способи протидії агентам впливу.

Постановка проблеми. Досвід України у протидії гібридній агресії показав, що держава-ініціатор гібридної агресії використовує всі можливі інструменти та механізми для досягнення стратегічної цілі деструктивного впливу на відповідні сфери національної безпеки держави, проти якої вона здійснює агресію. До того ж залучаються всі можливі ресурси, зокрема ресурси агентів впливу (“п'ята колона"), які разом 3 опозиційними силами та рухом опору спроможні забезпечити сприяння реалізації планів держави-агресора, особливо на початку (у прихованій фазі) зародження воєнного конфлікту. Незважаючи на широке використання понять “агент впливу” та "рух опору”, спроби їхнього суто практичного (юридично значущого) застосування викликають значну кількість проблем. У сучасних умовах сферами діяльності "агентів впливу” та “рухів опору" $\epsilon$ політична, економічна, інформаційна та частково військова. Організаційні форми їх діяльності в умовах демократичного суспільства та статуси “агентів впливу” роблять практично неможливим створення ефективної системи протидії, яка б ураховувала всі можливі варіанти їх деструктивної діяльності, що i підтверджує актуальність теми.

Аналіз останніх досліджень i публікацій. У сучасних дослідженнях та публікаціях [1-10] приділяється достатньо уваги проблемам протидії гібридній агресії. Насамперед це пов'язано із ситуацією на Сході України, де відносини між суспільством та політичним керівництвом держави піддавалося певним впливам з боку осіб, які на той час мали вплив на всі сфери життєдіяльності суспільства у Донецькій та Луганській областях і використовували це здебільшого у власних цілях. Водночас питанням нейтралізації, так званих, агентів впливу та рухів опору, які діють в інтересах держави-агресора приділяється недостатньо уваги.. Системних досліджень 3 цього питання у відкритих джерелах не виявлено.

Мета статті - обгрунтування рекомендацій щодо протидії агентам впливу та рухам опору, що діють в інтересах держави - ініціатора гібридної агресії.

Виклад основного матеріалу. За оцінками експертів російські геополітичні амбіції $\epsilon$ надзвичайно витратними, що обмежує можливості внутрішнього розвитку цієї країни. Це стимулює пошуки РФ можливостей обміну обтяжливих геополітичних активів на менш витратні, але більш для неї важливі, наприклад, встановлення контролю над Україною та іншими сусідніми країнами пострадянського простору. Російське керівництво й надалі докладатиме зусиль щодо схилення ключових провідних країн до компромісів завдяки привабливому для РФ вирішенню проблеми окупованих українських територій і надання ій права вето на характер і темпи європейської i євроатлантичної інтеграції України [10]. Більшість 3 цих завдань на сьогодні намагаються покласти на агентів впливу (AB) через використання протестного потенціалу опозиційних сил і створення рухів опору у нашій державі.

Під агентами впливу розуміються особи, які ведуть розповсюдження ідей будь- 
якої організації у середовищі, яке не належить до цієї організації. У політичній сфері агенти впливу зазвичай просувають інтереси іноземних держав або політичних партій. Такі особи $\epsilon$ каналом поширення пропаганди, впроваджують ворожі наративи та меседжі в інформаційному просторі, забезпечують видимість суспільної підтримки чи осуду певних політико-управлінських рішень. У більш радикальних випадках вони можуть використовуватися для дестабілізації політичної системи держави, порушення суспільної злагоди та роздмухування конфліктних тем тощо. За даними [8] часто діяльність таких агентів впливу може майже не відрізнятися від їхньої повсякденної професійної діяльності, проте, реалізується в певному ракурсі. Наприклад, зменшення фінансування певних напрямів наукової чи військової сфери, ініціювання скорочень у структурах, що можуть становити небезпеку для іншої держави, під приводом “реформ" чи “оптимізаціï”. Під поняттям рух опору (PO) розуміються організовані зусилля частини населення країни, що спрямовані на опір легітимній владі та підрив громадського порядку і стабільності, які зумовлюються рішучими діями для досягнення успіху, зокрема радикальними методами.

Основними сферами впливу агентів впливу та рухів опору є економічна, політична й інформаційна сфери національної безпеки. Основними завданнями ї діяльності, особливо на початковій фазі розв'язання державою-агресором збройного конфлікту $\epsilon$ створення соціально-політичної нестабільності у державі, дискредитація воєнно-політичного керівництва держави, введення в оману населення країни (через медійний простір) стосовно реалізації державної та воєнної політики. Це потребує не тільки оцінювання та прогнозування негативних наслідків їх діяльності для визначальних сфер національної безпеки, а й вироблення дієвих заходів протидії.

Запобігання несанкціонованим акціям, що організовуються $\mathrm{AB}$, зокрема за сприянням рухів опору має здійснюватися законними та легітимними методами, а організатори акцій нести юридичну відповідальність. В умовах дестабілізації соціально-політичної ситуації важливо проведення профілактичної та роз'яснювальної роботи серед населення країни 3 використанням усіх можливих ресурсів. Відомі методи протидії можна розділити на дві групи - профілактичні та оперативні. Ці методи застосовуються одночасно та мають спільну мету протидії агентам впливу та діяльності рухів опору, яка спрямована на дестабілізацію обстановки в державі.

Профілактичні методи, як свідчить досвід, є достатньо ефективним механізмом із запобігання загрози дестабілізації внутрішньої соціально-політичної обстановки на початковому етапі розвитку збройного конфлікту змістом якого $\epsilon$ створення протестного та масового руху опору державній владі. Оперативні методи використовуються як відповідь на дестабілізуючі та агресивні акції рухів опору під проводом АВ. На відміну від профілактичних заходів, що спрямовуються на запобігання загрозі ще до іiі зародження, оперативні методи запроваджуються вже після виявлення деструктивних впливів, які здійснюють рухи опору та організовуються агентами впливу (в окремих випадках за участі опозиційних лідерів). Запровадження оперативних методів потребує оцінювання ступеня загрози з боку АВ і РО та аналізу наявних ресурсів для нейтралізації (запобігання) їх деструктивної діяльності.

На прихованій фазі гібридної агресії найбільш ефективними методами протидії можуть бути методи, які використовують агенти впливу та рухи опору, але спрямовані суб'єктами сектору безпеки і оборони проти них самих. До таких методів доцільно віднести [11]:

персоніфікацію дій опозиційних сил та агентів впливу, тобто виказання конкретних осіб, які своїми діями призводять до масових безпорядків і матеріальних збитків державній власності та, що важливо, власності громадян;

деморалізація та делегімитизація учасників руху опору, лідерів опозиції та агентів впливу за допомогою критики в інформаційному просторі відомими особами країни, які мають авторитет у суспільстві;

оповіщення суспільства про відкриття адміністративних і кримінальних проваджень стосовно відомих агентів впливу, заколотників, активних учасників масових акцій протестів, діяльність яких може бути пов'язана 3 дестабілізацію суспільнополітичної обстановки;

заперечення інформації, що транслюється опозиційними 3MI, дискредитація їх в очах учасників протестів $\mathrm{i}$ лідерів рухів опору;

використання психологічних прийомів $\mathrm{i}$ технологій на масових опозиційних заходах, 
упровадження в маси спеціалістів відповідної кваліфікації для протидії діяльності різного роду провокаторів;

розгін несанкціонованих масових заходів і відкрита демонстрація сили державних органів влади;

активний моніторинг соціальних мереж AB i відомих лідерів РО, а також відслідковування і заборона координації та організації руху опору, блокування каналів передавання інформації та їх сторінок у соціальних мережах;

заборона активних медіаканалів антидержавних, які мають деструктивний вплив на суспільно-політичну, економічну та інформаційну сфери національної безпеки держави тощо.

За даними [12, 13] дієвим способом протидії деструктивним чинникам впливу на суспільно-політичну обстановку в країні, яка впроваджується агентами впливу за допомогою створених ними рухів опору та упередженою опозицією, є спосіб в основу якого покладено моніторинг державою підконтрольних АВ 3МI та ідентифікація інформації, яка може бути використана для введення суспільства в оману та просування інтересів держави-агресора (особливо в інформаційній, політичній та економічній сферах).

Важливість своєчасної та ефективної протидії деструктивним факторам, які реалізують агенти впливу та опозиційні сили обумовлена, насамперед тим, що саме успішність їх дій $\epsilon$ каталізатором нарощування протестного руху та плацдармом для реалізації наступного етапу дій у рамках стратегіï гібридної агресії, який отримав у фахівців РФ назву Стратегія "Троянського коня" [14]. Цей етап полягає в активізації угруповання сил спеціальних операцій (ССО) противника, що може бути завчасно приховано створене на території держави проти якої розв'язано агресію. У разі успішних дій агентів впливу та опозиції 3 дестабілізації

соціально-політичної

обстановки, ССО противника розпочинають активні дії при одночасному нарощуванні чисельності протестантів під виглядом добровольців та мирних мігрантів. Цілями дій угруповання ССО на цьому етапі гібридної агресії $\epsilon$ дезорганізація державного та військового управління, створення перешкод економічній діяльності, взяття під контроль сил опозиції та збір інформації. Важливим $є$ завдання 3 ліквідації найбільш небезпечних, 3 огляду на організацію протидії агресору, державних діячів або їх підкуп та виведення 3 ладу найбільш важливих об'єктів критичної інфраструктури держави [10] під маскуванням масових заворушень мирних громадян.

3 появою на території держави - жертви агресії незаконних збройних формувань (НЗФ) та іноземних найманців завдання угруповання ССО розширюються, а саме завдання управління бойовиками, контроль за діями іноземних збройних формувань, координація дій агентів впливу; зачистка фактів і доказів участі у дестабілізації обстановки в країні; ліквідація агентів впливу, що не виконали завдання або діяли всупереч планам. Після переходу агресора до відкритої підтримки НЗФ регулярними силами угруповання ССО виконують завдання 3 інформаційного забезпечення їх дій. Лише з початком прямої агресії (вторгнення на територію противника регулярних збройних формувань) стратегія Троянського коня на думку аналітиків завершується.

Питання пошуку та протидії агентам впливу (передусім російським) загострилося 3 початком бойових дій у 2014 році. Водночас досі актуальною проблемою $є$ формування достатньої нормативно-правової бази для притягнення таких осіб до відповідальності, механізмів їх чіткої ідентифікації та недопущення використання поняття “агент впливу" для обмеження свободи слова та думки. Іноземні держави (передусім 3 демократичними політичними системами) так само шукали і шукають механізми протидії. У статті як рекомендація пропонується удосконалення асиметричної протидії державі - агресору, що переважає у військовому та економічному відношенні в частині протидії агентам впливу. Відомо з [6], що асиметричні дії притаманні конфліктній ситуації, у якій заходами економічного, дипломатичного, інформаційного та безпосередньо воєнного характеру більш слабкий противник проводить асиметричну стратегію (тактику) ведення збройної боротьби, відповідно до наявних у нього обмежених ресурсів, для нівелювання воєннотехнологічних переваг сильної сторони. Однак законодавство країни проти якої здійснюється агресія не завжди може швидко адаптуватися під реальну ситуацію, що потребує пошуку асиметричних дій [4]. Основні напрями удосконалення асиметричної протидії (АП) агентам впливу наведено на рис. 1 .

Важливою умовою ефективності проведення заходів асиметричної протидії $\epsilon$ точне визначення найбільш уразливих i 
слабких місць противника, вплив на які дасть максимальний ефект за мінімальних затрат власних сил i ресурсів. Основним бажаним результатом асиметричної протидії має стати відмова противника від активних воєнних дій, тобто деескалація загрози воєнного або гібридного характеру до прийнятного (допустимого) рівня [6].

До критичних груп осіб, які мають бути у полі постійного відслідковування діяльності 3 боку відповідних державних безпекових структур і мають відповідні офіційні можливості для здійснення впливу: журналісти; експерти (урядові та неурядові, зокрема керівники НДУ); політичні діячі; популярні блогери; державні службовці (від середньої ланки і вище); науковці; радники (при державних органах або окремих посадових особах); творчі працівники (актори, митці та інші); релігійні діячі [8]. Крім указаних груп, окрему складність щодо ідентифікації агентів впливу становлять особи, які перебувають біля "статусних" суб'єктів і можуть впливати на них: чоловіки/дружини, співмешканки/співмешканці, родичі та інші особи.

Напрями удосконалення асиметричної протидії гібридним загрозам щодо протидії агентам впливу та рухам опору

\begin{tabular}{|c|c|}
\hline $\begin{array}{c}\text { Визначення критеріїв віднесення тих чи } \\
\text { інших осіб та організацій до агентів } \\
\text { впливу }\end{array}$ & $\begin{array}{c}\text { Удосконалення нормативно-правової бази щодо } \\
\text { забезпечення правових основ протидії агентам } \\
\text { впливу }\end{array}$ \\
\hline $\begin{array}{c}\text { Розроблення механізмів недопущення } \\
\text { використання поняття “агент впливу” } \\
\text { для обмеження свободи слова й думки } \\
\text { впливу }\end{array}$ & $\begin{array}{c}\text { Виявлення іноземних громадян агентів впливу, } \\
\text { які мають доступ до інструментів масового } \\
\text { впливу, залишаючись у межах чинного } \\
\text { українського законодавства }\end{array}$ \\
\hline
\end{tabular}

Рис. 1. Напрями удосконалення асиметричної протидії державі-агресору, яка переважає у військовому та економічному відношенні в частині протидії агентам впливу у системі кадрових органів

Своєчасне виявлення деструктивної діяльності агентів впливу, лідерів рухів опору державній владі та їх ефективна нейтралізація в умовах організації асиметричної протидії державі-агресору (за результатами проведених розрахунків) підвищує ймовірність прийняття противником рішення на відмову від застосування військової сили на $10 \%$ та зменшує час i ресурси на організацію асиметричної протидії [6].

За розрахунками своєчасна нейтралізація агентів впливу та рухів опору зменшує на 15$20 \%$ використання ресурсів на організацію та здійснення асиметричної протидії державіагресору, що проводиться, як правило у формі спеціальної операції [6].

Складність виявлення та нейтралізації агентів впливу підтверджує той факт, що за даними [8], наприклад, у США робота своєрідних "колективних агентів впливу" або спроба створення квазімережі агентів впливу (з-поміж осіб, наближених до чинного президента США) в межах поточного розслідування щодо втручання у виборчу кампанію 2016 р. кваліфікується американським слідством за іншими статтями кримінального права.
Важливим ресурсом у боротьбі 3 агентами впливу $\epsilon$ громадські організації, діяльність яких спрямована на зміцнення державних інституцій та забезпечення державного суверенітету. Для забезпечення участі громадськості у виявленні підривної інформаційної діяльності, здійснюваної, зокрема, агентами впливу та протидії дезінформації суспільства доцільно створити певну структуру. Наприклад, це може бути Комісія $з$ протидії дезінформації та підривній інформаційній діяльності. 3 урахуванням світового досвіду та зважаючи на особливості показників довіри громадян до ключових інституцій, задіяних у захисті національних інтересів, можна сформувати вимоги до моделі цієї структури:

основна робота має бути реалізована представниками громадянського суспільства, здійснюватися прозоро та за чіткими критеріями;

структура має бути належним чином інституалізована державою для надання відповідного юридичного статусу іiі діяльності;

важливо, щоб держава (iї представники) не мали повного контролю за тим, як 
структура функціонує, але за допомогою певних механізмів задавали формат іiі роботи.

Станом на сьогодні вирішення будьяких складних питань в інформаційній сфері (зокрема, контроль за контентом) є ключовим світовим трендом і всебічно підтримується міжнародним співтовариством, зокрема міжнародними організаціями та національними урядами, що забезпечить опосередковану підтримку цієї ініціативи на зовнішній арені.

\section{Висновки}

1. Запобігання несанкціонованим акціям, що організовуються опозиційними силами за допомогою агентів впливу має здійснюватися законними та легітимними методами, а організатори акцій нести юридичну відповідальність.

2. Доцільним є закріплення в українському законодавстві поняття “агент впливу” та введення відповідальності не лише за діяльність цих осіб на території України, а й за співпрацю з ними.

3. Потребує удосконалення нормативноправова база щодо притягнення агентів впливу до відповідальності 3 визначенням механізмів їх чіткої ідентифікації та недопущення використання поняття “агент впливу” для обмеження свободи слова та думки.

4. Рекомендацією $є$ удосконалення системи протидії гібридним загрозам завдяки вирішенню проблемних питань протидії агентам впливу в умовах асиметричної протидії гібридній агресії РФ.

5. Серед основних середньострокових загроз політичній стабільності варто вказати використання Росією агентів впливу серед політичних партій, громадських і релігійних організацій для провокування громадянського протистояння й політичної кризи.

6. На прихованій фазі гібридної агресії методами протидії доцільно вважати методи, які використовують агенти впливу та рухи опору, але спрямовані суб'єктами сектору безпеки і оборони проти них самих.

Напрями подалыших досліджень полягають в удосконаленні існуючих методів протидії агентам впливу та рухам опору на території, яка стала жертвою агресії, пошуку нових механізмів протидії деструктивним впливам з боку недружніх держав.

\section{СПИСОК ВИКОРИСТАНОЇ ЛІТЕРАТУРИ}

1. Михайло Гончар, Володимир Горбач, Сергій Савченко. Осінь гібридного наступу. Операція
“Через народовладдя до федералізації”. URL: https://zn.ua/ukr/internal/osin-hibridnoho-nastupuoperatsija-cherez- naodovlad dja-dofederalizatsiji.html (дата звернення: 09.02.2021).

2. Моделі i ціна врегулювання конфлікту на Донбасі: міжнародний досвід та українські реалії / Філіпчук В., Октисюк А, Поворозник В, Ярошенко $\epsilon$. // Міжнародний центр перспективних досліджень (МЦПД). 2016. С. 1118.

URL:

http://icps.com.ua/assets/uploads/images/images/eu/d onetsk.pdf (дата звернення: 09.02.2021).

3. Доброгурський В. І., Дублян О. В. Рекомендації щодо визначення завдань складовим інтегрованого потенціалу асиметричної протидії в інтересах здійснення контролю території збройного конфлікту. Актуальні проблеми застосування наиіональної гвардії України для здійснення контролю території збройного конфлікту неміжнародного характеру : зб. тез доп. наук.-практ. семінару. (Харків, 27 лист. 2020 р.). Харків, 2020. С. 9-13.

4. Воєнні аспекти протидії "гібридній" агресії: досвід України : монографія / колектив авторів ; за заг. ред. А. М. Сиротенка. Київ : НУОУ ім. Івана Черняховського, 2020. 176 c.

5. Леонов В. В., Ворович Б. О. Парадокс асиметрії в сучасних міжнародних збройних конфліктах. Збірник наукових пращь Центру воєнностратегічних досліджень Національного університету оборони України імені Івана Черняховського. 2016. № 1 (56). С. 29-34.

6. Богданович В. Ю., Сиротенко А. М., Дублян О. В. Концепція асиметричної протидії ворожій державі для нейтралізації її впливу на визначальні сфери національної безпеки України. Наука $i$ техніка Повітряних Сил Збройних Сил Украӥни. Харків, 2020. № 3 (40). C. 7-11.

7. Комплексна модель процесу протидії гібридній агресії / В. Ю. Богданович, А. М. Сиротенко, О. В. Дублян, О. В. Передрій, В. П. Малінко. Вісник воєнної розвідки. Київ, 2020. № 61. С. $93-$ 98.

8. Про внутрішнє та зовнішне становище України в 2018 році : Аналітична доповідь до Щорічного Послання Президента України до Верховної Ради України. Київ : НІСД, 2018. 688 с. URL: https://niss.gov.ua/sites/default/files/2019-

02/Analit_Dopovid_Poslannia_2018.pdf (дата звернення: 12.02.2021).

9. Світова гібридна війна: український фронт : колект. монографія / за заг. ред. В. П. Горбуліна. Київ : НІСД, 2017. 494 с.

10. Деякі питання об'єктів критичної інфраструктури : Постанова Кабінету Міністрів України від 09.10.2020 p. № 1109. URL: https://zakon.rada.gov.ua/laws/show/1109-2020\%D0\%BF\#Text (дата звернення: 06.02.2021).

11. Юсупова-Фарзалиева Д. М. Информационнокоммуникативные технологии как основа “цветных революций” в современных политиях : автореф. дисс. ... канд. полит. наук. Пятигорск, 
2012. 24 c. URL: https://www.dissercat.com/content/informatsionnokommunikativnye-tekhnologii-kak-osnovatsvetnykh-revolyutsii-v-sovremennykh-p звернення: 06.02.2021).

12. Пономарева Е. Г. Секреты “цветных революций”. Современные технологии смены политических режимов. Свободная мысль. 2012. № 1-2. С. 43-59.

13. Меркурьев В. В., Противодействие
Агапов П. В.

$$
\text { технологиям “цветных }
$$

революций” в системе мер по предупреждению преступлений против основ конституционного строя и безопасности государства. Всероссийский криминологический журнал. 2014. № 2. С. 63-71.

14. Сивков Константин “Троянский конь” агрессия нового типа. Военно-промьшиленный курьер. 2020. 8-14 сентября. (№ 34 (847)) URL: http://www.vpk-news.ru (дата звернення: 12.02.2021).

Стаття надійшла до редакційної колегії 09.03.2021

\section{Recommendations for countering influence agents and resistance movements acting in the interests of the state initiating hybrid aggression}

\section{Annotation}

The experience of Ukraine in countering hybrid aggression has shown that the state initiating hybrid aggression uses all possible tools and mechanisms to achieve the strategic goals of destructive influence on the relevant spheres of national security of the state against which it is carrying out the aggression.

In modern conditions, the spheres of activity of "influence agents" and "resistance movements" are political, economic, informational and partly military. The issues of neutralizing the so-called influence agents and resistance movements that act in the interests of the aggressor state are not given enough attention, its specificity. No systemic studies on this issue have been found in open sources.

The purpose of the article is to substantiate recommendations on counteracting influence agents and resistance movements acting in the interests of the state-initiator of hybrid aggression.

It is advisable to consolidate the concept of "influence agent" in Ukrainian legislation and introduce responsibility not only for the activities of these persons on the territory of Ukraine, but also for cooperation with them.

The regulatory and legal framework for bringing "influence agents" to justice with the definition of mechanisms for their clear identification and prevention of the use of the concept of "influence agent" to restrict freedom of speech and thought needs to be improved.

The recommendation is to improve the system of counteraction to hybrid threats by solving problematic issues of counteraction to influence agents in the conditions of asymmetric counteraction to hybrid aggression of the Russian Federation.

In the latent phase of hybrid aggression, it is advisable to consider methods used by influence agents and resistance movements, but directed by the subjects of the security and defense sector against themselves.

Keywords: influence agents; asymmetric counteraction; hybrid aggression; resistance movement; special operation; methods of counteraction; ways to counteract the agents of influence. 